\title{
Role of Orphanages to Uplift the Socio-Economic Status of Orphans Focusing on SOS Children's Villages in Punjab, Pakistan
}

\author{
Madieha Akram
}

Ph.D Student, Department of Sociology, Government College University, Faisalabad, Pakistan

Faiza Anjum

Ph.D Student, Department of Sociology, Government College University, Faisalabad, Pakistan

Nida Akram

M.Sc Psychology and Advanced Diploma in Clinical Psychology, Bahauddin Zakariya University, Multan, Pakistan

Corresponding author's e-mail: faizaanjum723@gmail.com

\section{Doi:10.5901/mjss.2015.v6n3s2p177}

\begin{abstract}
The present study has been designed to examine the effect of the upbringing environment on the development of orphan children and their achievement. This study also explores the socio-economic status of orphans regarding the role of the institution. Three save our soul children's village i.e. Multan, Faisalabad and Lahore were selected as a population of the present study. The simple random sampling technique was used to draw the sample from the target population; about 125 respondents (i.e. Orphans) in the age group of 8 to 14 years were selected for interview. A well designed questionnaire was used to gather the information from children who were living in save our soul children's village. The study found that save our soul children village plays an important role in the life of orphans as majority of the children were satisfied with all the facilities. It resulted in, save our soul children village is one of the major organizations working in Pakistan that provide a peaceful shelter with all the basic necessities (food, education, health care) to vulnerable children and orphans. Finally, there was an interaction between children's upbringing environment and effortful control of the institution, because of the environments they live in make them useful citizens of the society.
\end{abstract}

Keywords: Orphanages; Orphans; Socioeconomic Status; Institutionally-reared children.

\section{Introduction}

Children are fundamental assets and the future of a nation. The society should offer them sufficient opportunities for their proper physical, mental, social and moral growth as well as personality development and education (Abro, 2012). The families are the best place for the socialization of children; and it is the duty of the state to provide social services and social protection, as well as ensuring the integrity of the family. Parents are responsible for caring and supporting of their children and sometimes in the absence of parents, grandparents or other close relatives willingly are being taken responsibilities of their grandchildren.

The orphan child is whom one or both parents have been dying, desertion, or unable to provide care (UNICEF, 2008). Orphans are the susceptible children, below the age of eighteen years that faced core problems; have a great risk to discontinue within the threats to food, accommodation, health care or to make short their education. A huge number of orphans universally are alive with no natural relations due to diversity of causes together with: death of parents, separation between parents, domestic injurious treatment and disregard. The most frequent causes of separation of children from parental care include poverty, lack of access to basic services, abuse, neglect, disease, disabilities, and emergencies (Bilson \& Cox; 2007). It is an indignity of all social members who are not giving attention and economic assistance towards orphans (Meintjes and Bray, 2006). If any child does not have such relatives who can support him, then the orphanages are only one way to provide him/her shelter, health care, food, education and accommodation. An orphanage is a resident organization which is dedicated for concern native to child whose parents are dead or else they are not able to support their children (The Faith to Action Initiative, 2014). In other words, an institution and placement of offspring's whose biological guardians are dead otherwise not capable or else reluctant to look after their children is 
called orphanage (wisegeek, 2003-2015). It is a housing care service of children that is planned to care for children from the time of their entrance awaiting their adulthood or liberation, and which holds itself out as a satisfactory or better alternative for the families of the children. The functions of the orphanages have been providing a home where infants are brought up to serve as alternative actors in welfare, development and to save the failed role of the state in child protection.

The one important orphanage is Save Our Soul (SOS) children's village founded in 1949 by a young Austrian medical student, Hermann Gmeiner; later than nationwide relations had been recognized in France, Germany as well as Italy plus the unique Austrian friendship. It is a self-governing global advance union, operational to fulfill the wants plus defend the well-being as well as civil obligations related to. In excess of a hundred nationwide links crossways the world has since been recognized; currently there are 2,000 SOS Children's Village facilities worldwide. In adding up to the Save our Soul Children's Villages the organization is running an entire variety of programs as well as conveniences in favor of publicly deprived as well as poor groups to increase the standard of their lives. It also supports different other programs like running educational institutions, managing health care centers in addition to programs for street offspring. Such children are supported to get well as of life form, expressively disturbed and to keep away from genuine hazard of being lonely, ill-treated, browbeaten plus disadvantaged of their human rights.

\subsection{Save our Soul Children's Villages in Pakistan}

In Pakistan, an orphan is a huge phenomenon, a higher rate of emotional and mental shock; the effect on the lives of orphans is grave. People, particularly children are affected by a large number in the days of political instability and natural disasters. They became homeless, parentless as well as deprived from all the basic necessities of life. It is very hard for many families to bear the expenses of education and medical facilities and they are forced to send their children to earn their livelihood (Ali, 2010). The other reason behind this phenomenon is that people had many children where people married earlier, but there was a higher death rate among adults; a lot of off spring's lost their single or both parents in their early age. Those children that born to parents who were not married, their life is also like a barren if no one supports them. In this result, orphans have not all basic necessities of life; they are living outside of normal life, either they are in an orphanage or adopted by any family.

The social protection sector has broader objectives and functions in a multi-dimensional discipline in Pakistan. It fulfills wishes to the welfare of needy, impoverished, poor, disabled, socially and economically burdened individuals of the society and systematize communities into productive self-supporting units of evolution. It is running different projects for the welfare and rehabilitation of underprivileged and susceptible children of our society, e.g. Neghaban (for the lost, kidnapped and runaway children), Gehwara (abandoned babies home), Chaman (center for the treatment and rehabilitation of mentally retarded children) and Children Homes (Evaluation Report on Project, 2013).

Save our soul children's village is working in Pakistan since 1975 which helps people in every critical situation. Whenever there is a need, SOS children's village is supporting the vulnerable families permanently in shape by providing health facilities, providing educational facilities and psychoanalysis. Moreover, in major disasters, the SOS children's village is providing relief aid to the Pakistani people. SOS village is working in twelve areas of Pakistan for gratifying children's basic needs; the first project, which started was the save our soul children's village in Lahore. Government of Pakistan is trying to improve literacy rate and save our soul Hermann Gmeiner Schools donating their support in this regard in eight areas of Pakistan. SOS children's villages are giving vocational training to young people as well as providing them special accommodation and other basic facilities of life. In vocational institutes, the youth is guided through professional ways to achieve their aims to an independent life. The Social centers running under the SOS children's villages are well equipped and full of trained medical staff for dealing with misfortune and emergency relief programs. (SOS Children's Villages of Pakistan, 2005).

The present study focuses on the important aspect of the society called orphanage that evaluates the role of save our soul children's villages. This study also touches the area of socialization includes inculcating of the educational level of orphans, which further defines the socio-economic status of the orphans.

\section{Research Methods}

The present method was planned to examine the socio-economic status of orphan as well as the role of save our soul children's villages in it. These villages are an autonomous, non-governmental worldwide progressive society which has been working to meet up the requirements as well as defend the welfare plus human rights of children. The universe of the study was comprised of save our soul (SOS) children's villages of Punjab province. The total number of save our soul 
(SOS) children's villages in Punjab province is seven. Multi-stage sampling technique was used to select the final unit. At the first stage, three SOS villages namely Multan, Lahore and Faisalabad were selected through simple random sampling technique from seven SOS villages. The population of the study composed of all the orphans who were living in SOS children's villages of Multan, Faisalabad and Lahore during the data collection. The total population of these three SOS villages was 401 children. At the second stage, a sample of 125 respondents (i.e. Orphans) in the age group of 8 to 14 years was taken randomly with equal percentage from each selected SOS children's village. The reason to choose this age limit was because of at 14 or 15 years of age, orphans move into SOS youth homes for girls or for boys, where they receive a close and individual attention. For obtaining responses, information was gathered by using the tool of social survey. A well designed Questionnaire was built in relevance to the study and it was based on structured questions. The gathered information was examined through applying SPSS (Statistical Package for Social Sciences); descriptive analysis, such as percentages and frequency distribution was used to evaluate the data.

\section{Results and Discussion}

Table 1: Distribution of the Respondent's Personal Information $(n=125)$

\begin{tabular}{|c|c|c|c|}
\hline Categories & N (Percentage) & Categories & N (Percentage) \\
\hline Age & & \multicolumn{2}{|c|}{ Reason of Presence in SOS } \\
\hline Less than 10 & $25(20.0)$ & Death of Parents & $103(82.4)$ \\
\hline $11-12$ & $52(41.6)$ & Others & $22(17.6)$ \\
\hline $13-14$ & $48(38.4)$ & \multicolumn{2}{|c|}{ Duration of Stay at SOS (years) } \\
\hline Sex & & Less than 5 & $25(20.0)$ \\
\hline Boy & $66(52.8)$ & $6-8$ & $78(62.4)$ \\
\hline Girl & $59(47.2)$ & $9+$ Above & $22(17.6)$ \\
\hline Education & & Self-awareness & $108(86.4)$ \\
\hline Primary & $59(47.2)$ & Yes & $17(13.6)$ \\
\hline Middle & $38(30.4)$ & No & \\
\hline Matriculation & $28(22.4)$ & & \\
\hline
\end{tabular}

Table 1 indicates that majority $41.6 \%$ of the respondents were belonging to the age group 11 - 12 years and majority 52.8 $\%$ of them were boys. The functions of learning are very important in all fields' life. Education can influence noteworthy better results in the lives of vulnerable as well as orphan children's. The educational level of the respondents shows that all children are getting education. Mostly parentless children are living in SOS children's villages as shown in the result; a significant number, $82.4 \%$ of the respondents got the residence in SOS after death of their parents. A number of children misplaced a single father or mother; a few together, in addition to, several are effective children with the intention of evicting on the roads through their relatives, and however they are weak as well as to require aid. It is the job of the family to fulfill the basic requirements of the children, help the children to achieve their goals by concluding their attitudes towards religion and society norms. Due to the general scarcity of resources and lack of social service structures in many impoverished countries, the vast majority of orphaned children are living in orphanages. Children who do not have parents/guardians are susceptible to the extent because they do not have a caring from adults to protect them from unsafe circumstances or from the peoples who can be exploit them (Bailey, 2006; Nyawasha, 2012).

According to the result, majority $62.4 \%$ of respondents were staying in SOS from 6 to 8 years (see table 1). SOS has youth homes for young girls and boys separately, children are living till their marriage. Those children, who got jobs and left SOS, also remain attached to it till the end of their lives. Duration of stay is not specific for living in save our soul children's village. Children must have self-awareness because it is the capability to have an obvious understanding of one's own strengths, weaknesses, thoughts and ideas. Children have very low level of self-awareness as majority $76.4 \%$ of children reported that they have not self-awareness (see table 1 again). Some common psychological problems like anxiety, fear, lack of confidence, stress, isolation and depression leads to inferiority and complex; and these all factors create hurdles in self-awareness (Muhwezi, 2009). In fact awareness about own self is a necessary initial stage in the direction of increasing managerial qualities. Through it a person can get better results, plus assist to recognize the occasions for skilled occupation as well as personal development. 
Table 2: Distribution of the Respondents Regarding to What Extent they are satisfied with the Facilities Provided by SOS villages $(n=125)$

\begin{tabular}{|c|c|c|c|}
\hline Categories & To great extent & To some extent & Not at all \\
\hline & N (Percentage) & N (Percentage) & N (Percentage) \\
\hline Sufficient Food & $62(49.6)$ & $34(27.2)$ & $29(23.2)$ \\
\hline Peaceful Shelter & $88(70.4)$ & $26(20.8)$ & $11(8.8)$ \\
\hline Proper Education & $68(54.4)$ & $40(32.0)$ & $17(13.6)$ \\
\hline Health Care & $64(51.2)$ & $20(16.0)$ & $41(32.8)$ \\
\hline Recreational activities & $59(47.2)$ & $39(31.2)$ & $27(21.6)$ \\
\hline
\end{tabular}

Table 2 shows the facilities that are provided by SOS villages to children. It depicts that mostly $49.6 \%$ of children were agreed to a great extent that SOS is giving them better food while $27.2 \%$ and $23.2 \%$ of the respondents were agreed to some extent and disagreed respectively. Food is significant for everyone, but it is particularly important for children because it is in a straight line connected with their process of growing in addition to progression; very closely effected on their adult age. It provides sufficient facilities and livelihood needs of orphans are the prime aim of successful orphanages.

The fundamental nature of relations is a necessary task of save our soul children's villages. Because of this children's are living in the shape of groups collectively like siblings with the intention to attain a family atmosphere. It is the central function of SOS to provide a peaceful environment for these orphans; through this policy child feels safety and a sense of association with relations. Almost two third percent of the children were satisfied to the greatest extent that SOS villages are a peaceful shelter for them (see table 2).

More than half $54.4 \%$ of the respondents were agreed to a great extent that SOS children's village is providing them proper educational facilities as shown in table 2. It is concluded that the SOS children's village is committed to all children, receiving their right to education. When equipped with knowledge, skills and ambition, children can grow up to live happy, empowered lives, and be valuable members of their society. Around the world, save our soul children's village works to provide a holistic education to children that develops cognitive, social, emotional, physical and vocational skills (Ksoll, 2007). Education is a self-enlighten process and development of an individual and the society at large; it provides information, leads to career succession, builds character, leads to enlightenment, and helps in nation progress.

Almost half $51.2 \%$ of the respondents were agreed that SOS is providing them proper health care facilities (see table 2). The needs of children's health are as well considerably dissimilar as of mature persons. In a natural environment, offspring's raise as well as build up at quick rates; they are in particular danger of being influenced via ill health plus wound. If fitness evils are not recognized, furthermore deal with, they can influence a child's perception, body, passionate and emotional growth.

SOS is also providing recreational activities because of its huge importance as the results describes that $47.2 \%$ and $31.2 \%$ of the respondents were agreed to great extent and to some extent respectively about recreational facilities provided by SOS (see table 2 again). It helps orphans in reducing stress and helps them relax as well as refresh their senses. Just work without any recreational activity makes boy/girl fully dull. Rest and recreational activities are very important for healthy development of body and mind. Leisure is also useful for psychological health. Amusement brings positive change in life. Entertaining actions are often done for pleasure, laughter, or enjoyment and are considered to be fun. These activities imply participation to be healthy stimulating mind and body.

Table 3: Distribution of the Respondent's perception about SOS Villages $(n=125)$

\begin{tabular}{|l|c|c|c|}
\hline Categories & Agree & Neutral & Disagree \\
\hline & N (Percentage) & N (Percentage) & N (Percentage) \\
\hline SOS is a Proper Place of Living for Orphans & $108(86.4)$ & $10(8.0)$ & $07(5.6)$ \\
\hline The Environment of SOS is Close to a Natural Home & $72(57.6)$ & $32(25.6)$ & $21(16.8)$ \\
\hline SOS provides a Platform for Personality Development & $79(63.2)$ & $16(12.8)$ & $30(24.0)$ \\
\hline The administration's attitude is good/friendly for them & $62(49.6)$ & $34(27.2)$ & $29(23.2)$ \\
\hline
\end{tabular}

Table 3 illustrates that a significant $86.4 \%$ of the respondents informed with the aim of that SOS children's village is a proper place of living for orphans while a negligible part $5.6 \%$ claimed that SOS is not a proper place of living for orphans. 
The institutions are responsible for children's supervision, residence, in addition to imparting of knowledge.

Save our soul children's villages provides them safety, plus affection as majority $57.6 \%$ were agreed to a great extent that the setup of SOS is like a natural home (see table 3). The vision of the save our soul is that: every child belongs to a family; each offspring lives with love, all children's lives with respect, and grows with security. By living in a family, every child feels defensive as well as enjoying relations; provides a more permanent feeling of home, a more efficient environment in which to mature. In SOS, offspring's gain knowledge of the principles, contribute to everyday jobs and shape lifelong relations.

Better care is necessary for the personality development of children; it encourages individuals to look at the brighter sides of life. They are ready to tackle the most horrible situations with a smile. The data depict that respondents who agreed were $63.2 \%$ to SOS is providing a platform for their personality development (see table 3 ). An orphan's personality refers to his or her look, individuality, approach, state of mind and performance with others. Save our soul children's villages are putting great attention on that these orphans are not blindly following others. Personality development not only makes orphans good looking as well as well turned-out but also helps them face the world with a smile. Personality development goes a long way in dropping anxiety and conflicts.

About $49.6 \%$ of children were agreed that the administration's behavior is good /friendly with them (see table 3 again). In the opinion of some people the basic needs of human beings are water, shelter and food. Though, the basic needs of children are very complicated. Children are the crops of their surroundings and their basic needs also related to mental and emotional conditions. A child, who belongs to an unsteady environment, can't live a happy life, shows maladjustment everywhere and looks like an angry person. So these children require more attention, care, affection for good wellbeing.

\section{Conclusion}

On the bases of the results it is concluded that most of the responders were pleased with the presentation belonging to the SOS villages in Pakistan; consider it is a proper place of living for the orphans that provides them all necessities of life and convert them into a good person. Save our soul trying its best to provide quality education for the orphans as well as an appropriate environment like home for all children and managing the facilities of recreational activities also. SOS is providing health care facilities to orphans because the significance of healthiness within the individual life span cannot be diminished. SOS builds the capacity of children and makes them useful citizens for the development of Pakistan; it paved the way for a good career of children. In fact, all basic facilities are provided in save our soul children's village for the wellbeing of children; it's considered as a requirement of most excellent social and economic progression of children. With the growing tendency of population growth, income inequality and poverty the number of orphans is increasing day by day; so there is a need to build more orphanages like SOS villages and enhance the Space in the existing orphanage. SOS villages should more focus on the education and personality development strategies. If a person has selfawareness, he can easily tackle the problems with better decisions and without any hesitation, he can choose a way to achieve a bright future. This type of people can motivate others with their successful personalities and can perform their duties in a better way than others.

\section{References}

Abro, A. A. (2012). The Problems of Street Children: A Sociological Study of Urban Sindh. Ph.D thesis, University of Karachi, Karachi. [Online] available: http://eprints.hec.gov.pk/9360/1/6696H.html.

Ali, G. (2010). Economic Factors Responsible for Child Labor (A Case study of District Swabi). Journal of Managerial Sciences, V(1): 8696.

Bailey, J.D. (2009). Orphan Care: An Introduction. Social Work and Society. 7(1): 1-12.

Bilson, A., \& Cox, P. (2007). Caring about Poverty. Journal of Children and Poverty, 13(1): 37-49.

Evaluation Report on Project. (2013). Establishment of Seven Model Homes in Five District of Punjab. Directorate General of Monitoring and Evaluation, Planning and Development Department: Government of the Punjab. [Online] Available: dgmepunjab.gov. pk/index.php?option=com_rubberdoc...

Ksoll, C. (2007). Family Networks and Orphan Caretaking: Tanzania. [Online] Available: www.economics.ox.ac.uk/materials/.../ paper361.pdf.

Muhwezi, W.W., Muhangi, D., \& Mugumya, F. (2009). Intra-household Differences in Health Seeking Behaviour for Orphans and Nonorphans in an NGO-supported and Non-supported Sub-county of Luwero, Uganda. Afr Health Sci. 2009 Jun; 9(2): 109-117.

Meintjes, H., \& Bray, R. (2006). Spinning the Epidemic: The Making of Mythologies of Orphan hood in the Context of AIDS in Childhood. 3, pp.407-430. 
Nyawasha, T.S., \& Chipunza, C. (2012). "An Assessment of Psychosocial and Empowerment Support Interventions for Orphans and Vulnerable Children in Zimbabwe. J Hum Ecol, 40(1): 9-16.

SOS Children's Villages of Pakistan. (2005). [Online] Available: http://www.pakpost.gov.pk/ philately/stamps2005/sos.html.

SOS Children's Villages: A brief History. [Online] Available: http://www.soschildrensvillages.ca/sos-childrens-villages-brief-history.

The Faith to Action Initiative. (2014). Children, Orphanages and Families: A Summary of Research to Help Guide Faith-Based Action. [Online] Available: http://faithtoaction.org/wp-content/uploads/2014/03/Summary-of-Research.pdf.

UNICEF. (2008). [Online] Available: http://www.unicef.org/media/media_45279.html.

Wisegeek. (2003-2015). [Online] Available: http://www.wisegeek.com/what-is-an-orphanage.htm\# Copyright @ 2003 - 2015 Conjecture Corporation. 